\title{
VISUALIZATION CAPABILITIES OF SIMULATION OF ECONOMIC PROCESSES
}

\author{
Peteris GRABUSTS \\ Dr. sc. ing., professor, Rezekne Academy of Technologies, Rezekne, Latvia, \\ e-mail: peter@ru.lv, phone: +37126593165
}

\begin{abstract}
Educational experience shows that during the research process researchers perceive graphical information better than analytical relationships. Many economic courses operate with models that were previously available only in mathematics and physics disciplines. As a possible solution, there could be the use of the package Matlab Simulink in the realization of different algorithms both for engineering disciplines and economic studies. The article substantiates the usefulness of implementing the simulation models during the early stage of the research, when in parallel to acquiring analytical relations, simulation models may be introduced. The aim of the article is to show Matlab Simulink suitability for the purpose of visualizing simulation models of various economic disciplines. To reach the aim, the following research tasks have been set: identification of Matlab Simulink possibilities for simulation of economic processes; demonstrate visualization models on the basis of examples; visualization of time series model using Latgale unemployment rate data. The article presents examples of using simulation modeling in the economic research processes - optimal tax rate searching and time series application. Common research methods are used in this research: descriptive research method, statistical method, mathematical modeling.
\end{abstract}

Keywords: Matlab Simulink, modeling, simulation, teaching, visualization. JEL code: $C 63$

\section{Introduction}

The classification of general economic models is based on the scope of the economic system under study. From this point of view, the models can be divided into three major groups: the models of firms, industry models and macroeconomic models.

The model should be based on solid empirical basis. However, this information is usually not available for developers of economic models. The management of companies simply do not wish to give their business details to the third person. This is especially true for companies operating in the face of strong competition.

The aim of the research study on different simulation models is the formation of a researcher's theoretical knowledge and practical skills in the use of simulation modeling techniques in research of solving specific problems in modeling of real economic applications. During the course, researchers get acquainted with the means of simulation modeling processes of functioning systems, master the simulation modeling 
methods and typical stages of modeling process that form the "chain": the construction of the conceptual model and its formalization - model algorithmization and its computer implementation - simulation experiment and interpretation of the results of the modeling; acquire practical skills for implementation of modeling algorithms for studies of characteristics and behaviour of complex economic systems (Kay, 1984; Karel \& Tomas, 2015).

Simulation - the most powerful and versatile method for studying and evaluating the effectiveness of systems, the behaviour of which depends on the influence of random factors.

The implementation of such opportunities in the universal programming language is a difficult task. Currently, there is quite a lot of software that allows to model processes. However, now there is a product that allows solving these problems quite effectively - the MATLAB package (Kiusalaas, 2016; Siauw \& Bayern, 2015; Smith, 2013) containing a visual simulation tool - Simulink (http://se.mathworks.com/products/ simulink/). Simulink - a tool that allows you to simulate the system quickly, get the indexes of expected effect and compare them with the amount of effort required to achieve them (Karel \& Tomas, 2015; Xue \& Chen, 2013).

The article substantiates the usefulness of implementing the simulation models during the early stage of the research, when in parallel to acquiring analytical relations, simulation models may be introduced.

The main aim of the article is to show Matlab Simulink suitability for the purpose of visualizing simulation models of various economic disciplines.

To reach the aim, the following research tasks have been set:

- identification of Matlab Simulink possibilities for simulation of economic processes;

- demonstrate visualization models on the basis of examples;

- $\quad$ visualization of time series model using Latgale unemployment rate data.

A study was carried on using Matlab Simulink capabilities in the optimal tax rate modeling and in the application of time series analysis possibilities with the help of Simulink.

To demonstrate the practical use of a time series with the help of Matlab, data on the unemployment rate in Latgale in the years 1996-2015 from the Latvian Central Statistical Bureau was taken.

Common research methods are used in this research: descriptive research method, statistical method, mathematical modeling. 


\section{Possibilities of the software package Matlab Simulink}

Of particular interest for simulation is a Simulink tool designed specifically for modeling dynamical systems. It has a library of standard graphics units with built-in mathematical functions. It is sometimes called a tool of visual modeling (Shiflet \& Shiflet, 2014; Silva, 2009).

Although Simulink is designed mainly to solve engineering and scientific- technical problems, the possibilities of its use are almost unlimited. The input of initial parameters is made interactively by graphics assembly of elementary blocks circuit diagram, resulting in a model of the studied system. The blocks included in the model relate to each other both in information and in management. The type of connection depends on the type of the block and the logic of the model.

The Simulink program is an application to the MATLAB package. The simulation, using Simulink, implements the principle of visual programming whereby the user on the screen creates a model of a structure, process or system from standard blocks of the library, and performs calculations. In this case, unlike in classical ways of modeling, the user does not need to study the programming language and numerical mathematics methods thoroughly, there is enough to have some general knowledge required when working on the computer, and, of course, knowledge on the subject area in which he works.

Creating a model in this way, and then launching it, it is possible to see the results of modeling. In the simulation, the user can choose the method for solving equations, as well as the way to change the model time (with a fixed or variable step). During the simulation, it is possible to monitor the processes happening in the system. To this purpose, special viewing devices that are part of the Simulink library are used. The simulation results can be presented in the form of graphs or tables.

Series of research were carried out in order to demonstrate the Simulink suitability for simulation model visualization purposes in different engineering disciplines. It should be noted that often the analytical solution is much simpler than the visual Simulink model, but in perspective, it gives an understanding of such models usefulness.

Figure 1 shows the used blocks' description and its explanation given in the examples.

The Discrete Time Integrator block (Commonly Used Blocks) performs discrete-time integration or accumulation of a signal. We use this block in discrete-time systems instead of the Continuous Integrator block in continuous-time systems. The block can integrate or accumulate using the Forward Euler, Backward Euler, and Trapezoidal methods. 


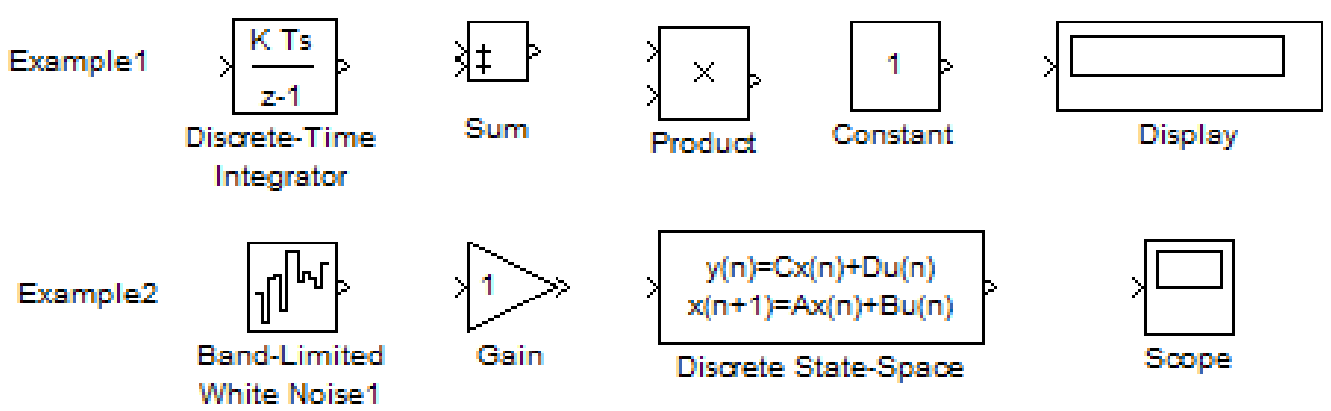

Figure 1. Blocks used in the examples (Source: author's construction)

The Product block (Commonly Used Blocks) block performs multiplication or division of its inputs. This block produces outputs using either element-wise or matrix multiplication, depending on the value of the Multiplication parameter.

The Sum block (Commonly Used Blocks) performs addition or subtraction on its inputs. This block can add or subtract scalar, vector, or matrix inputs.

The Constant block (Sources) is used to define a real or complex constant value.

The Display block (Sinks) shows the output value at the end of the simulation time.

The Band Limited block (Sources) is an implementation of white noise into Zero-Order Hold block.

The Gain block (Commonly Used Blocks) multiplies the input by a constant value (gain). The input and the gain can each be a scalar, vector, or matrix. We specify the value of the gain in the Gain parameter.

The Discrete State-Space block (Discrete) implements the system described by the equations: $x[n+1]=A x[n]+B u[n] y[n]=C x$.

\section{Research part}

Example 1. Optimal Tax Rate searching

The aim of the experiment: to study the dependence of budget revenues on the tax rates. The author used the (Cisar, 2004) study results.

The state announces the income tax rate and receives funds from the companies to the budget. Companies have their own capital, get profit, and pay funds to the budget according to the tax rate. After-tax profit as retained earnings is fully included in the company's own capital. Dividends are not paid out, no other deductions from income are done. All profit is divided only into two flows: to the budget and the rest-to the equity.

Budget revenues for a certain period of time will be the greatest not at the maximum but at the optimum tax rate for the budget. That is, with 
the growth of the tax rate, the revenues to the budget will increase and then decrease.

The amount of tax revenues from enterprises for the simulated period is stored in the fiscal accounts, and is represented by the integral:

$$
B D(t)=\int_{t=t b}^{t=t f} P R F(t) * T X R T * d t
$$

where $\mathrm{BD}(\mathrm{t})$ - amount of funds received in the budget from the beginning of the simulation till the moment $t$, euro;

PRF $(t)$ - pretax profit, derived by an enterprise at the moment $t$, euro/year;

TXRT - income tax rate;

$\mathrm{t}$ - current time, year.

$\mathrm{tb}$-beginning moment of simulation;

$\mathrm{tf}$ - final moment of simulation.

A profit balance capitalized by an enterprise during the simulation time:

Profit at time t:

$$
C P(t)=\int_{t=t b}^{t=t f} P R F(t) *(1-T X R T) * d t
$$

$$
P R F(t)=C P(t) * R N
$$

where RN - profitability of the enterprise capital. It is set as a parameter of the enterprise, initial data.

The model of such a process is shown in Figure 2.

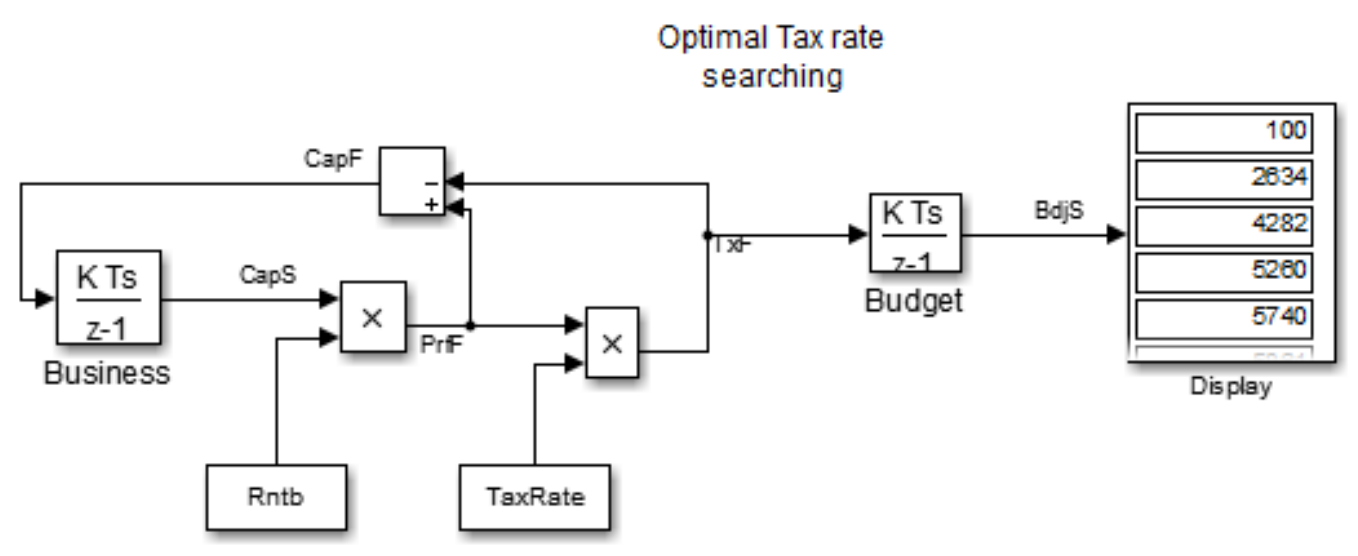

Figure 2. Optimal tax rate searching model

(Source: author's construction - adapted from Cisar, 2004)

In the scheme block Business, there is presented the hoarder of the equity of the enterprise, it is taken from the library of elements as a block 
Integrator of discrete time. The investment flow CapF enters on the block input. It is after-tax, retained profit. It is accumulated by a business and increases its equity capital. Block Out - is the amount of capital in business CapS. Profitability is defined by a block with the name Rntb. The next block works out the multiplication of the profit flow on the tax rate Tax Rate. This is the flow of deductions from profits to the state budget TxF. The tax rate is set with the name Tax Rate. The block Budget is represented by the integrator. It accumulates tax revenues $\mathbf{T x F}$ for the simulation period as a variable BdjS. The block Display reflects numerical values of BdjS.

The optimal tax rate modeling result is shown in Figure 3.

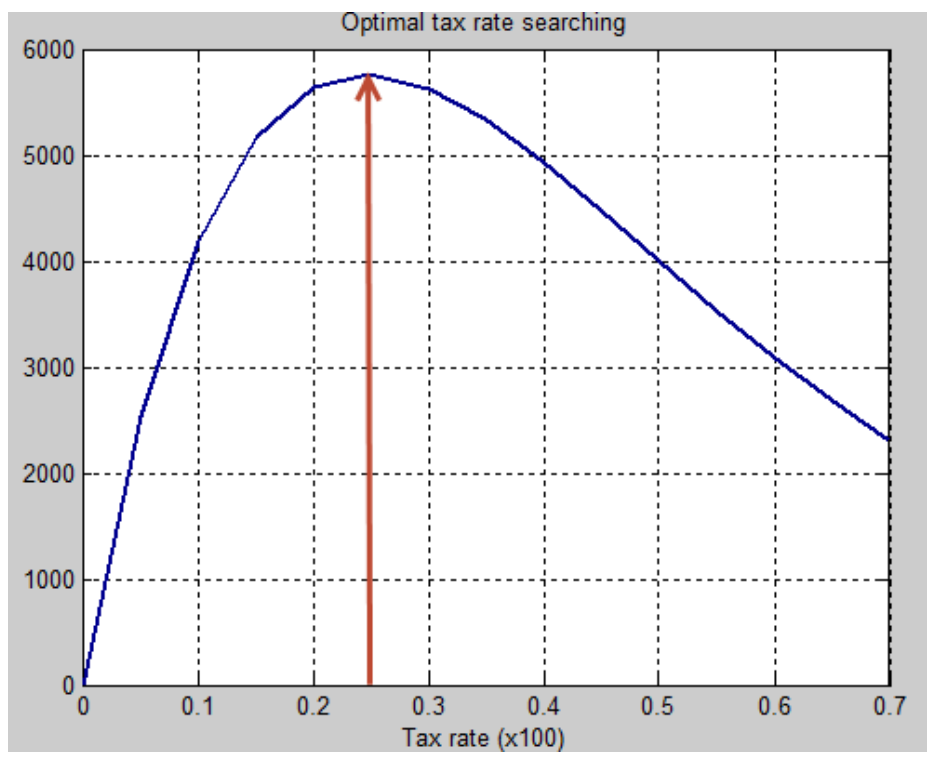

Figure 3. Optimal tax rate (Source: author's construction)

With increasing rates, the revenues to the budget increase and then decrease. There is a strongly marked maximum, i.e., the optimal tax rate for the budget. The higher the profitability of the enterprise is, the more pronounced the optimal tax rate is. With the growth of the profitability, the optimal rate is reduced (shifted to the left), aiming at a fixed value, on our charts, approximately, to 23 - 25\%.

Example 2. Economic time series data modeling

A time series is a sequence of real numbers that represent the measurements of a real variable at equal time intervals, whereas a time series database is a collection of time series (Kirchgassner and Wolter, 2007; Lutkepohhl, 2005; Tsay, 2002; Montgomery et. al., 1988). Time series data can be analysed in many different ways. For instance, to perform this task various mathematical models can be used. 
Time sequences appear in many applications, to be more precise, in any applications that involve a value that changes over time. There is one problem concerning the time sequences has been paid a lot of attention to recently, i.e., the problem of similarity retrieval of time sequences in databases, or the so called "query by example" (Vlachos and Gunopulos, 2004).

The ARMA model is offered (Montgomery et. al., 1988) with the help of following equation:

where $\sigma^{2}=4$.

$$
y_{n}=10+0.6 y_{n-1}+u_{n}+0.9 u_{n-1}
$$

The matrices for the discrete state-space representation of the disturbance are as follows: (Nembhard and Nembhard, 1996):

$$
A=\left[\begin{array}{cc}
0.6 & 0.9 \\
0 & 0
\end{array}\right] \quad B=\left[\begin{array}{l}
1 \\
1
\end{array}\right] C=[10] \quad D=[0] .
$$

The theoretical time series simulation model (Nembhard and Nembhard, 1996) is shown in Figure 4 and Figure 5.

The following graph illustrates that simulation methods can be used in time series analysis. It can be used as an example to demonstrate Simulink possibilities in changing various parameters of simulation model. It should be noted that the use of real data in this model is quite unwieldy.

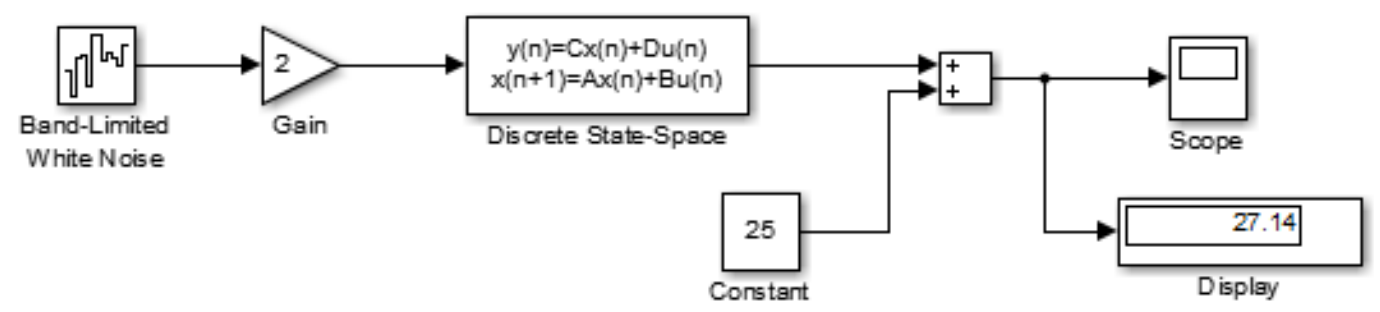

Figure 4. Time series ARMA process simulation model (Source: author's construction - adapted from Nembhard and Nembhard, 1996)

To demonstrate the practical use of a time series with the help of Matlab, data on the unemployment rate in Latgale in the years 1996-2015 (see Table 1) from the Latvian Central Statistical Bureau was taken.

In graphical form it is shown in Figure 6. This data time series is shown in Figure 7. 


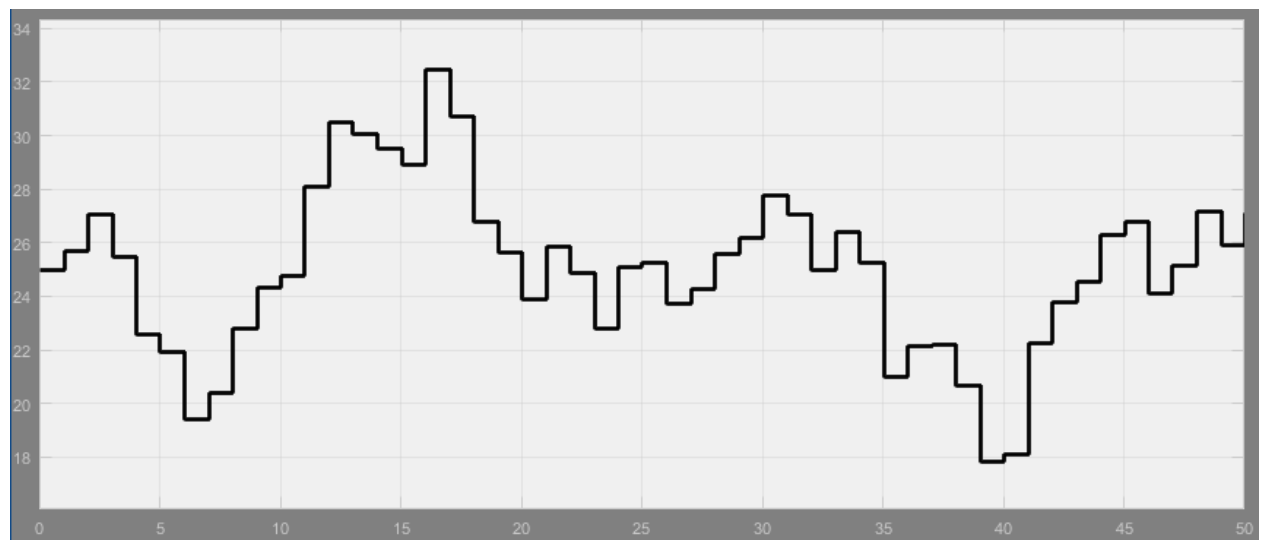

Figure 5. Realization of the ARMA random stream process (Source: author's construction - adapted from Nembhard and Nembhard, 1996)

Table 1

Unemployment rate in Latgale (Source: CSB, 2016)

\begin{tabular}{|l|c|c|c|c|c|c|c|c|c|c|}
\hline Year & 1996 & 1997 & 1998 & 1999 & 2000 & 2001 & 2002 & 2003 & 2004 & 2005 \\
\hline $\begin{array}{l}\text { Level } \\
(\%)\end{array}$ & 23.4 & 16.7 & 17.0 & 21.9 & 20.9 & 20.8 & 18.5 & 18.0 & 14.6 & 14.5 \\
\hline
\end{tabular}

\begin{tabular}{|l|c|c|c|c|c|c|c|c|c|c|}
\hline Year & 2006 & 2007 & 2008 & 2009 & 2010 & 2011 & 2012 & 2013 & 2014 & 2015 \\
\hline $\begin{array}{l}\text { Level } \\
(\%)\end{array}$ & 11.6 & 8.7 & 9.6 & 18.0 & 19.5 & 19.0 & 20.9 & 17.3 & 17.3 & 19.0 \\
\hline
\end{tabular}

UNEMPLOYMENT RATE IN LATGALE (\%)

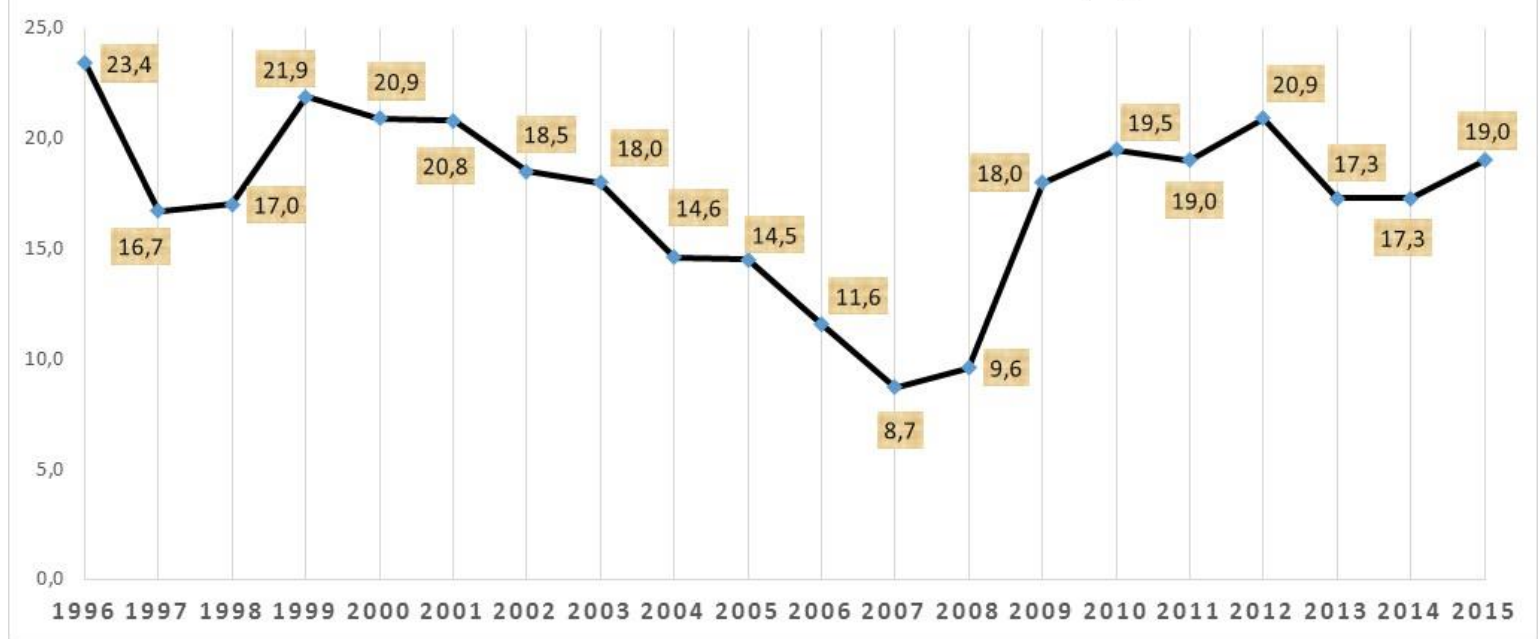

Figure 6. The unemployment rate over the years (Source: author's construction) 
Although in this case, the visual model may seem complicated, but its further understanding makes it possible to create complex system models - not only in engineering, but also in economics, environmental sciences, sociological studies, and so on (Anderson, 2005; Cerný, 2009; Chapra \& Canale, 2015).

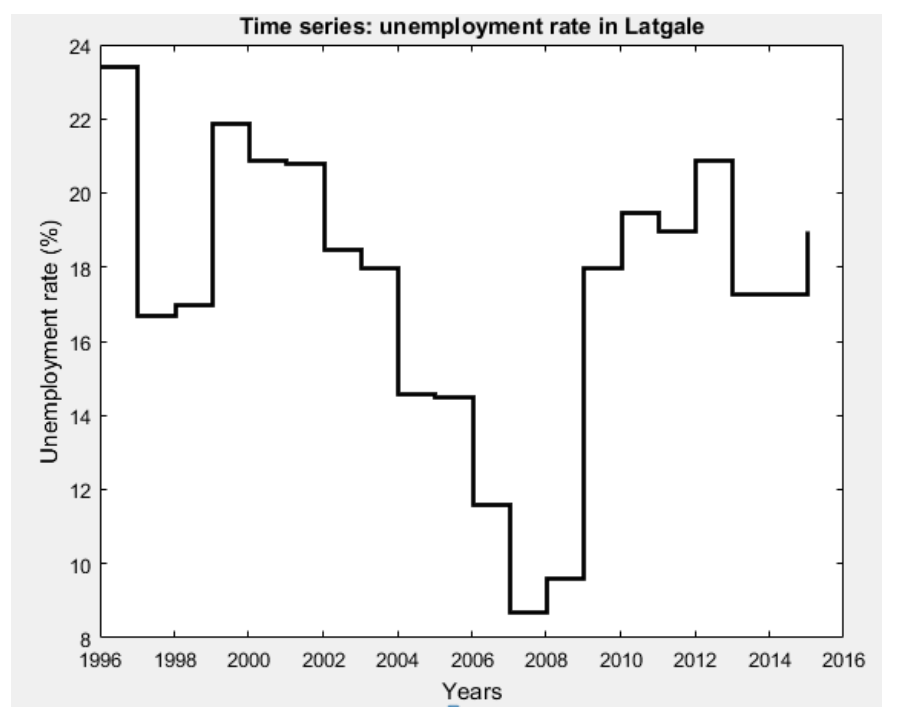

Figure 7. Time series graph (Source: author's construction)

\section{Conclusions}

In this article the author substantiates the usefulness of introduction of a simulation model for the economics studies. It gives researchers the opportunity to visualize different correlations in graphical form.

In study part the possibilities of simulation modeling for economic studies are demonstrated - optimal tax rate searching and time series application. As a practical example, the time series acquisition from data on the unemployment rate in Latgale is shown. In further studies, the author intends to focus on time series forecasting.

The author is assured that the use of simulation models makes it possible to raise a researcher' horizon and gives an idea of the potential uses of such models.

Thus it can be concluded that the Matlab Simulink tool is a very suitable tool not only in engineering calculations, but also can serve as a simulation model visualization tool in various science fields. 


\section{References}

1. ANDERSON, P.L. (2005). Business Economics and Finance with MATLAB®, GIS, and Simulation Models. Chapman \& Hall, $472 \mathrm{p}$.

2. CERNY, A. (2009). Mathematical Techniques in Finance: Tools for Incomplete Markets, $2 e$. Princeton University Press, $416 \mathrm{p}$.

3. CHAPRA, S.C., CANALE, R.P. (2015). Numerical Methods for Engineers, $7 e$. McGraw-Hill, 992 p.

4. CISAR, I. (2004). Simulink for economists, for Mathworks. Inc. Retrieved April 10, 2016, from http://matlab.exponenta.ru/simulink/book3/3.php

5. $\quad$ CSB (CENTRAL STATISTICAL BUREAU). (2016). Labour force survey in 19952014 (only in Latvian). Retrieved April 16, 2016, from http://www.csb.gov.lv/ en/dati/e-publikacijas/labour-force-survey-1995-2014-only-latvian-43358. html

6. KAY, C. (1984). Mathematics for Computer Programmers. New Jersey: Prentice Hall.

7. KAREL, P., TOMAS, Z. (2015). Multimedia Teaching Aid for Students of Basics of Control Theory in Matlab and Simulink. Procedia Engineering, Volume 100, 150158.

8. KIRCHGASSNER, G., WOLTER, J. (2013). Introduction to modern time series analysis. Berlin: Springer, 320 p.

9. KIUSALAAS, J. (2016). Numerical Methods in Engineering with MATLAB, 3e. Cambridge University Press, 430 p.

10. LUTKEPOHHL, H. (2005). New introduction to multiple time series analysis. Berlin: Springer, $764 \mathrm{p}$.

11. MONTGOMERY, D.C., JOHNSON, L.A., GARDINER, J. (1990). Forecasting and time series analysis. Second edition. McGraw-Hill, Inc., New York, 381 p.

12. NEMBHARD, H.B., NEMBHARD D.A. (1996). Dynamic simulation for time series modeling. Proceedings of the 1996 Winter Simulation Conference.

13. SHIFLET, A.B., SHIFLET, G.W. (2014). Introduction to Computational Science: Modeling and Simulation for the Sciences, $2 e$. Princeton University Press, $856 \mathrm{p}$.

14. SIAUW, T., BAYERN, A. (2014). An Introduction to MATLAB Programming and Numerical Methods for Engineers. Academic Press, 340 p.

15. SILVA de, C.W., (2009). Modeling and Control of Engineering Systems. CRC Press, Inc, $766 \mathrm{p}$.

16. SMITH, D. (2013). Engineering Computation with MATLAB, 3e. Pearson Education Inc, $464 \mathrm{p}$.

17. TSAY, R.S. (2002). Analysis of financial time series. John Wiley \& Sons, 448 p.

18. VLACHOS, M., GUNOPULOS, D. (2004). Indexing time series under condition of noise. Data mining in time series database: Series in machine perception and artificial intelligence. World Scientific Publishing, Vol.57, pp. 67-100.

19. XUE, D., CHEN, Y. (2013). System Simulation Techniques with MATLAB and Simulink. John Wiley \& Sons, Inc, 488 p. 


\title{
EKONOMISKO PROCESU MODELĒ̌̌SANAS VIZUALIZĀCIJAS IESPĒJAS
}

\author{
Pēteris GRABUSTS \\ Dr.sc.ing., Rēzeknes Tehnoloğiju akadēmija, profesors
}

Kopsavilkums

Pieredze rāda, ka pētnieki izziṇas procesā daudz labāk uztver grafisko informāciju, nevis analītiskās sakarības. Daudzi kursi operē ar modeḷiem, kas agrāk bija pieejami tikai matemātikas un fizikas disciplīnās. Kā iespējamais risinājums būtu paketes Matlab Simulink izmantošana dažādu algoritmu realizācijā gan inženierzinātṇu disciplīnās, gan arī ekonomiskajos pētījumos.

Tika veikta pētījumu sērija, lai demonstrētu Matlab Simulink piemērotību dažādu ekonomisko disciplīnu simulācijas modeḷu vizualizācijas nolūkā. Jāatzīmē, ka bieži vien analītiskais risinājums ir daudz vienkāršāks, nekā vizuālais Simulink modelis, taču perspektīvā tas dod sapratni par šādu model̦u izmantošanas lietderīgumu. Lai arī šajā gadījumā vizuālais modelis varētu likties sarežǵīts, taču tā izpratne turpmāk dod iespēju veidot kompleksus sistēmu model̦us - ne tikai inženierzinātnēs, bet arī ekonomikā, vides zinātnēs, sociologiskajos pētījumos utt.

Šajā pētījumā autors pamato simulācijas modeḷu ieviešanas lietderību jau sākotnējā pētījumu procesā, kad paralēli analītisko sakarību apgūšanai var ievest arī simulācijas modelus.

Pētījumu dạ̦ā tiek demonstrētas modelēšanas iespējas ekonomiskajos pētījumos - optimālās nodokḷu likmes skaitlıšanā un laikrindu analīzē. Kā praktisks piemērs ir parādīta laikrindu iegūšana no datiem par bezdarba līmeni Latgalē. Turpmākajos pētījumos autors plāno pievērsties laikrindu prognozēšanai.

Tādējādi var secināt, ka Matlab Simulink ir l̦oti piemērots rīks ne tikai aprēḳinu veikšanai, bet arī var kalpot kā simulācijas modeḷu vizualizācijas rīks dažādās zinātṇu jomās.

Atslēgas vārdi: Matlab Simulink, modelēšana, simulācija, vizualizācija. 